\title{
Makna "Letih Lesu dan Berbeban Berat" dalam Injil Matius 11:28 Berdasarkan Prinsip Hermenetika Injil
}

\author{
Yosua Sibarani \\ Sekolah Tinggi Teologi Happy Family \\ yosuasibarani@stthf.ac.id
}

\begin{abstract}
A reader of the Bible should know that ancient copies of the Old and New Testaments sometimes use different or inexact wordings regarding certain texts. This fact shows that the Bible needs to be interpreted based on the principle of correct interpretation so that today's readers understand the meaning of the text that is being read. The text of the Gospel of Matthew 11:28 is one of the many biblical texts that Christians have misunderstood as a result of the preacher's error in presenting it. This study aims to describe the concept of "tired and heavy laden" in Matthew 11:28 based on the interpretive principle that places Matthew specifically as one of the Gospels in the New Testament canon using qualitative research methods. As a result of this research, the phrase "weary and laden with weight" refers to Jews who are exhausted from carrying out the demands of the law for salvation, not to people who experience problems or problems of daily life of a physical nature.
\end{abstract}

Keywords: Weary; Heavy Laden; Invitation of The Savior; Hermeneutics; Gospel

\begin{abstract}
ABSTRAK
Seorang pembaca Alkitab perlu mengetahui bahwa salinan kuno dari Perjanjian Lama dan Perjanjian Baru kadang-kadang menggunakan susunan kata yang berbeda atau tidak sama persis mengenai teks tertentu. Fakta tersebut menunjukkan bahwa Alkitab perlu ditafsirkan berdasarkan prinsip penafsiran yang benar agar pembaca masa kini memahami makna teks yang sedang dibaca. Teks Injil Matius 11:28 adalah salah satu dari sekian banyak teks Alkitab yang disalahpahami oleh orang Kristen sebagai akibat dari kekeliruan pengkhotbah menyampaikannya. Penelitian ini bertujuan untuk memaparkan konsep "letih lesu dan berbeban berat" dalam Matius 11:28 berdasarkan prinsip penafsiran yang menempatkan Matius secara khusus sebagai salah satu dari Injil dalam kanon Perjanjian Baru menggunakan metode penelitian kualitatif. Sebagai hasil dari penelitian ini, frase "letih lesu dan berbeban berat" merujuk kepada orang-orang Yahudi yang mengalami kelelahan karena melakukan tuntutan hukum Taurat untuk mendapatkan keselamatan, bukan orang-orang yang mengalami masalah atau persoalan hidup sehari-hari yang bersifat jasmani.
\end{abstract}

Kata Kunci: Letih Lesu; Berbeban Berat; Matius; Hermenetika

\section{PENDAHULUAN}

Alkitab adalah firman Allah yang ditulis ribuan tahun silam oleh kurang lebih 40 penulis dengan latar belakang yang berbeda. Ada beberapa jurang pemisah ( $g a p$ ) antara zaman penulis Alkitab ataupun pembaca mula-mula dengan zaman pembaca Alkitab/kanon masa kini, di antaranya adalah jurang budaya (cultural gap), jurang sejarah (historical gap), jurang geografi (geographic gap) dan jurang bahasa (linguistic gap). Selain itu, teks Alkitab yang diterima oleh pembaca masa kini telah melalui proses penyalinan dari generasi ke generasi. ${ }^{1}$ Oleh sebab itu, seorang pembaca Alkitab perlu mengetahui bahwa salinan kuno dari Perjanjian Lama dan Perjanjian Baru kadang-kadang menggunakan susunan kata yang berbeda atau tidak sama persis mengenai teks tertentu. Fakta tersebut menunjukkan bahwa Alkitab perlu ditafsirkan berdasarkan prinsip penafsiran yang benar agar pembaca masa kini memahami makna teks yang sedang dibaca.

${ }^{1}$ Craig L. Blomberg and Jennifer Foutz Markley, A Handbook of New Testament Exegesis (Malang: Gandum Mas, 2018), 17. 
Penafsiran memiliki signifikansi dalam proses memahami makna teks-teks dalam Alkitab. ${ }^{2}$ Alkitab merupakan sumber utama bagi umat Tuhan untuk mengenal pribadi, kehendak, dan rencana keselamatan-Nya. B. B. Warfield pernah berkata, "Alkitab adalah Firman dari Allah dalam cara sedemikian rupa sehingga pada saat Alkitab berbicara, saat itu Allah berbicara." ${ }^{3}$ Meskipun demikian, fakta menunjukkan bahwa terdapat penafsiran yang beragam dalam gereja dan mengakibatkan perbedaan teologi maupun denominasi. Tidak jarang ragam penafsiran terhadap satu teks tertentu dalam Alkitab dijumpai dalam gereja. Ada pengkhotbah yang mengkhotbahkan bagian Alkitab tanpa menggunakan prinsip penafsiran yang benar, atau bisa dikatakan tanpa melakukan penafsiran terhadap teks tersebut. ${ }^{4}$ Selain itu, buku-buku renungan rohani Kristen juga diisi dengan artikel yang lepas dari penafsiran bagian yang sedang dibahas.

Ajakan Juruselamat dalam Matius 11:28 adalah salah satu dari sekian banyak teks Alkitab yang disalahpahami oleh orang Kristen sebagai akibat dari kekeliruan pengkhotbah menyampaikannya. Pada bagian ini, Tuhan Yesus mengajak pendengar-Nya, "Marilah kepada-Ku, semua yang letih lesu dan berbeban berat, Aku akan memberi kelegaan kepadamu." Frase "letih lesu dan berbeban berat" seringkali mendapatkan makna yang kurang tepat oleh kalangan pengkhotbah atau orang Kristen. Dalam sebuah situs renungan Kristen, penulis menemukan penjelasan tentang makna "letih lesu dan berbeban berat" yang tidak sesuai dengan makna penulis teks Alkitab tersebut. Berkaitan dengan makna tersebut tertulis,

"Apa yang kita lakukan dengan beban ketakutan, kekhawatiran, dan kecemasan yang sering kita pikul sembari menjalani hidup yang penuh tantangan ini? Alih-alih bersandar kepada Tuhan, saya justru sering bersikap seperti wanita tadi. Tuhan Yesus berkata, "Marilah kepada$\mathrm{Ku}$, semua yang letih lesu dan berbeban berat, Aku akan memberi kelegaan kepadamu" (Mat. 11:28). Namun ternyata saya masih saja memikul beban yang seharusnya saya serahkan kepada Yesus." 5

Berdasarkan pernyataan di atas, pada umumnya pemahaman pembaca sekarang tentang frase "letih lesu dan berbeban berat" adalah masalah hidup yang dimiliki oleh orang Kristen. Tidak jarang orang Kristen zaman sekarang mendengar khotbah dari para pengkhotbah Kristen yang menafsirkan Matius 11:28 sebagai ajakan Yesus bagi mereka yang memiliki permasalahan hidup seperti masalah finansial, kesehatan, masa depan, jodoh, pekerjaan, atau persoalan jasmaniah lainnya. Apakah teks tersebut memang berbicara tentang hal tersebut? Jika tidak, apa makna teks tersebut yang sesungguhnya?

Penulis setuju dengan apa yang disampaikan oleh Hasan Sutanto, "Alkitab, Kitab Suci orang Kristen, tidak mudah dimengerti". Pembacanya membutuhkan pertolongan Roh Kudus untuk benarbenar menghayatinya. ${ }^{6}$ Oleh sebab itu setiap pembaca atau penafsir Alkitab perlu menerapkan prinsip penafsiran yang tepat sesuai keunikan masing-masing teks yang diselidiki dengan tetap bergantung pada intervensi dan supervisi Roh Kudus. Dalam penelitian ini, penulis akan memaparkan konsep "letih lesu 2007), 11

${ }^{2}$ Hasan Sutanto, Hermenetika: Prinsip Dan Metode Penafsiran Alkitab (Malang: Literatur SAAT,

${ }^{3}$ Roy B. Zuck, Hermenetika: Basic Bible Interpretation (Malang: Gandum Mas, 2014), 5.

${ }^{4}$ Yosua Sibarani, "Studi Evaluatif Model Khotbah Topikal Bagi Pengkhotbah Kristen," Juteolog: Jurnal Teologi 1, no. 1 (2020): 59-76.

5 "Letakkanlah Beban Anda | Santapan Rohani," accessed December 8, 2020, https://santapanrohani.org/2017/01/08/letakkanlah-beban-anda/.

${ }^{6}$ Sutanto, Hermenetika: Prinsip Dan Metode Penafsiran Alkitab, 18. 
dan berbeban berat" dalam Matius 11:28 berdasarkan prinsip penafsiran yang menempatkan Matius secara khusus sebagai salah satu dari Injil dalam kanon Perjanjian Baru.

\section{TINJAUAN PUSTAKA}

\section{Pengantar Injil Matius}

Penulis Injil Matius tidak menyebutkan namanya atau siapa yang menjadi penulis kitab tersebut. Para ahli pada umumnya berpendapat bahwa mustahil Injil ini ditulis oleh Rasul Matius sendiri, sebab dalam banyak hal Injil Matius mengambil alih isi Injil Markus dengan cara yang sangat harfiah (misalnya Mat. 14:22-27 dan Mrk. 6:45-50). ${ }^{7}$ Namun demikian, bapa gereja mula-mula telah meyakini bahwa penulis Injil Matius adalah Matius, rasul Tuhan Yesus Kristus. ${ }^{8}$ R. T. France menyatakan bahwa Patristic tradition in unanimous that the author was Matthew, and no other "Matthew" is suggested than the disciple of that name whose call is described in 9:9. ${ }^{9}$ Nama Matius pertama kali ditulis dalam Injil ini adalah di Matius 9:9. Ia adalah seorang Yahudi. Ia juga disebut Lewi (bukan dalam arti berasal dari keturunan suku Lewi). ${ }^{10}$ Nama Matius berasal dari kata Ibrani yang artinya "pemberian Allah". ${ }^{11}$ Matius menjadi saksi hidup pelayanan Yesus pada waktu itu.

Injil Matius ditujukan kepada orang-orang Yahudi. Oleh sebab itu, Injil Matius banyak mengutip bagian Perjanjian Lama yang kemudian mengatakan tergenapi dalam Perjanjian Baru. ${ }^{12}$ Injil ini mengutip Perjanjian Lama sebanyak 61 kali, di antaranya 37 kali didahului kalimat "hal ini terjadi supaya genaplah yang difirmankan Tuhan oleh nabi" (misalnya Mat. 2:5, 15; 3:3; 12:17; 13:14; $21: 4$ )." Injil Matius menghubungkan Perjanjian Lama dengan Perjanjian Baru lebih erat dibandingkan dengan Injil yang lain. Bahkan tidak ada dokumen lain dalam Perjanjian Baru yang memaparkan diri Yesus, hidup-Nya dan ajaran-Nya, demikian jelas sebagai penggenapan dari hukum Taurat dan nubuatan para nabi. ${ }^{13}$ Injil Matius lebih banyak mengutip Perjanjian Lama dibandingkan dengan Injil yang lain. Dengan demikian, tidak dapat dipungkiri bahwa Injil Matius ditujukan kepada orang Yahudi agar mereka percaya bahwa Yesus adalah Mesias, sebagaimana yang dinubuatkan dalam Perjanjian Lama. ${ }^{14}$ Leon Morris mengatakan bahwa injil Matius sangat sarat dengan sifat keyahudiannya karena Matius menuliskan penggenapan-penggenapan Perjanjian Lama di dalam injil ini. ${ }^{15}$

Tidak ada yang tahu dengan pasti kapan Injil Matius ditulis. Menurut Wycliffe, tanggal penulisan Injil Matius pasti sebelum 70 M, sebab di dalamnya sama sekali tidak disebutkan bahwa Yerusalem sudah menjadi puing (semua ramalan tentang kejatuhannya bersifat nubuatan). ${ }^{16}$ Merril C. Tenney tidak sependapat dengan argumentasi tersebut. Ia berpendapat bahwa kecil sekali kemungkinan Inji Matius ditulis sebelum orang-orang Kristen meninggalkan Yerusalem (Kis. 8:4). ${ }^{17}$ Hal ini disebabkan karena gereja di Yerusalem tentu tidak membutuhkan suatu Injil tertulis, karena masih ada para rasul yang akan menjawab setiap pertanyaan yang muncul dan memberikan pengajaran. Namun demikian, Merril C. Tenney juga tidak berpendapat bahwa Injil Matius ditulis setelah tahun $70 \mathrm{M}$ karena

\footnotetext{
${ }^{7}$ J. J. De Heer, Injil Matius Pasal 1-22 (Jakarta: BPK Gunung Mulia, 2013), 2.

${ }^{8}$ Marulak Pasaribu, Eksposisi Injil Sinoptik (Malang: Gandum Mas, 2005), 135.

${ }^{9}$ R. T. France, The Tyndale New Testament Commentaries: Matthew (Surabaya: Momentum, 2007), 37.

${ }^{10}$ David Imam Santoso, Theologi Matius: Intisari Dan Aplikasinya (Malang: Literatur SAAT, 2009), 2.

${ }^{11}$ Merrill C. Tenney, Survei Perjanjian Baru (Malang: Gandum Mas, 2011), 184.

12 Ibid.

13 "Matius," Ensiklopedi Alkitab Masa Kini Jilid II M-Z (Yayasan Komunikasi Bina Kasih, 2011), 38.

${ }^{14}$ M. E. Duyverman, Pembimbing Ke Dalam Perjanjian Baru (Jakarta: BPK Gunung Mulia, 2012), 46.

${ }^{15}$ Leon Morris, Teologi Perjanjian Baru (Malang: Gandum Mas, 2006), 156.

${ }^{16}$ Charles F. Pfeiffer and Everett F. Harrison, The Wycliffe Bible Commentary (Malang: Gandum Mas,

${ }^{17}$ Tenney, Survei Perjanjian Baru.
} 2011), 21 
ramalan mengenai kekalahan kota ini tidak pernah mengenai kehancurannya yang sesungguhnya (Mat. 24:1-28). Oleh karenanya para ahli kemudian berpendapat bahwa Injil ini ditulis di atas tahun $70 \mathrm{M}$. Berdasarkan penjelasan para ahli tersebut, penulis menyimpulkan bahwa Injil Matius ditulis antara tahun 60-70 M.

Tujuan penulisan Injil Matius tidak dapat dilepaskan dari konteks bangsa Israel secara menyeluruh, salah satunya adalah kondisi politis masyarakat Yahudi mulai pada masa akhir Perjanjian Lama sampai pada masa Perjanjian Baru. ${ }^{18}$ Tujuan utamanya adalah untuk memperkenalkan bahwa Yesus adalah Mesias, Anak Allah. ${ }^{19}$ Orang Yahudi sangat mempercayai Perjanjian Lama, sehingga Matius banyak mengutip dari Perjanjian Lama. Maka apabila bangsa Yahudi menerima dan percaya Perjanjian Lama, mereka seharusnya juga percaya akan apa yang dikisahkan dalam Injil Matius tentang Yesus. Jadi dapat dikatakan bahwa tujuan Matius menulis Injil Matius adalah untuk menginjili bangsa Yahudi agar mereka benar-benar percaya bahwa Yesus adalah Mesias sebagaimana yang dinubuatkan dalam Perjanjian Lama. ${ }^{20}$

Berdasarkan tujuan di atas, jelas dapat dikatakan bahwa tujuan tersebut bukan hanya untuk orang Kristen Yahudi pada waktu itu, atau hanya untuk memenuhi kebutuhan orang Kristen Yahudi pada waktu itu, melainkan juga untuk setiap orang Kristen dari segala zaman dari dahulu, sekarang dan yang akan datang. David Iman Santoso berpendapat bahwa pesan Yesus pada Matius 28:20 yang kemudian disebut sebagai Amanat Agung: "Ajarlah mereka melakukan segala sesuatu yang telah Kuperintahkan kepadamu. Dan ketahuilah, Aku akan menyertai kamu senantiasa sampai kepada akhir zaman" sebagai panggilan bagi seluruh orang Kristen untuk meneruskan pengajaran Yesus Kristus. ${ }^{21}$ Hal ini berarti bahwa ajaran Tuhan Yesus tetap relevan bagi setiap orang sampai pada akhir zaman.

Pembaca juga perlu mengerti tema-tema utama dalam memahami isi berita Injil Matius, sebab Injil Matius ini ditulis sebagai ungkapan dari apa yang ada dalam hati penulis Injil. Beberapa tema yang ingin disampaikan oleh Matius kepada para pembacanya adalah Allah diperkenalkan sebagai Bapa, Yesus diperkenalkan, Gelar-gelar Yesus, Pengajaran Yesus, Mujizat Yesus, Kerajaan Surga, Yesus dan Hukum Taurat, Misi, dan Pemuridan. ${ }^{22}$ R. T. France mengatakan: “The essential key to all Matthew's

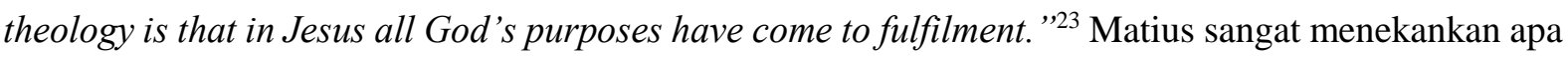
yang dikatakan oleh Yesus daripada perbuatan-Nya. Teolog Perjanjian Baru yang bernama R. V. G. Tasker memandang injil Matius sangat istimewa karena banyaknya ajaran moral dan spiritualitas Kerajaan Allah yang Yesus ajarkan. ${ }^{24}$

\section{Signifikansi Matius Sebagai Injil}

Kitab-kitab dalam Perjanjian Baru yang berjumlah 27 tidak menggunakan genre yang sama. ${ }^{25}$ Gordon D. Fee menyebutkan bahwa pada dasarnya Perjanjian Baru ditulis atas empat tipe sastra (genre), yaitu (1) surat yang terdiri atas paragraf-paragraf argumentasi atau nasihat, (2) Injil yang terdiri atas perikop-perikop, (3) Kisah Para Rasul berupa cerita singkat yang diselingi pidato-pidato, dan (4) Wahyu yang merupakan rangkaian penglihatan-penglihatan. ${ }^{26}$ Berdasarkan pembagian genre kanon Perjanjian Baru tersebut, tulisan tulisan Matius ini tergolong ke dalam genre Injil. Istilah "Injil” berasal

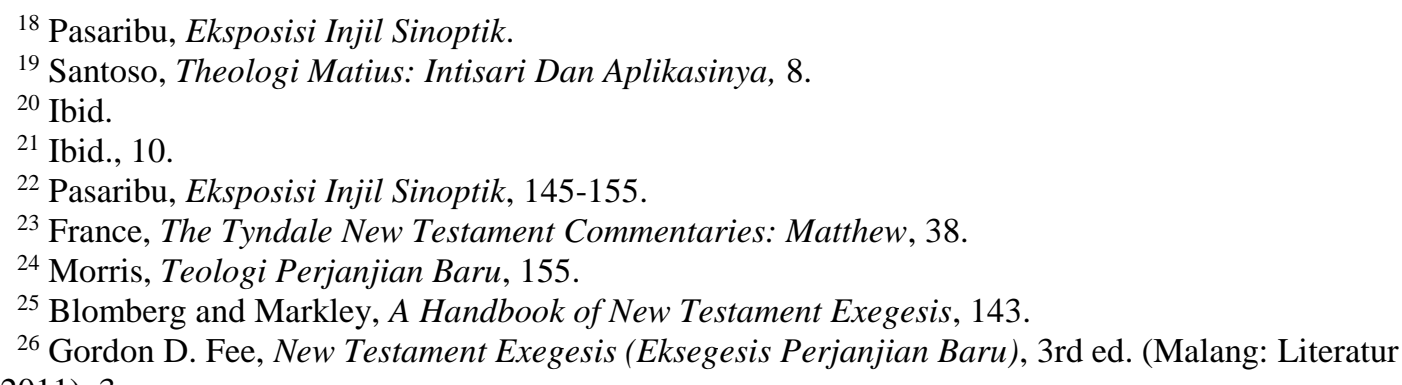
SAAT, 2011), 3 . 
dari nomina Yunani "euaggelion" yang secara umum berarti kabar atau berita baik. Kata "euaggelion" ini kemudian diterjemahkan ke dalam bahasa Inggris menjadi "gospel" yang secara etimologis berarti kabar baik dan baru yang membuat hati pendengar bergembira atau bersukacita. ${ }^{27}$ Kabar baik yang memberi sukacita tersebut adalah berita kelahiran, kematian, dan kebangkitan Yesus Kristus yang adalah Mesias, Anak Allah yang oleh-Nya manusia dapat diperdamaikan dengan Allah. ${ }^{28}$

Dalam kanonisasi Perjanjian Baru, ada 4 kitab yang digolongkan sebagai Injil, yaitu Matius, Markus, Lukas, dan Yohanes. Injil Matius adalah Injil yang paling terkenal dan paling banyak dikutip dari keempat Injil di dalam sejarah gereja. ${ }^{29}$ Bahkan Injil ini dikatakan sebagai Injil yang paling berpengaruh dari Injil yang lain. ${ }^{30}$ Injil Matius bersama dengan Injil Markus dan Lukas, biasanya disebut sebagai Injil Sinoptik. Istilah "sinoptik" ini pertama kali diberikan oleh J. J. Griesbach menjelang akhir abad 18, karena ketiga Injil intu mempunyai banyak persamaannya, sehingga dapat disusun dalam tiga kolom seperti sebuah synopsis, yaitu suatu pandangan di mana ketiganya dapat dibaca bersama. ${ }^{31}$ Kata "sinoptik" itu sendiri berasal dari kata "sun opsis," kata "sun" berarti bersama, opsis berasal dari kata "horao", yang artinya melihat. Jadi "sun opsis" berarti melihat bersama. ${ }^{32}$ Ini berarti bahwa Injil Matius, Markus, dan Lukas bisa dilihat dan dibaca bersama, karena memang isinya begitu mirip satu dengan yang lain, betapa pun tiap kitab mempunyai ciri masing-masing. ${ }^{33}$

Setelah Yesus bangkit dari kematian dan naik ke Sorga, selama kira-kira 30 tahun murid-murid Tuhan dan orang Kristen pada umumnya sedikit banyak mengalami kehilangan atau kekosongan rohani, mereka hanya bergantung pada ajaran Tuhan yang beredar secara lisan (oral tradition), mereka tidak mempunyai pegangan tentang ajaran Tuhan Yesus secara tertulis. Maka setelah Injil Matius ditulis, Injil inilah yang dipegang dan paling sering dibaca serta dipelajari oleh gereja pada waktu itu. David Iman Sansoto mengutip Francis Beare mengatakan, "The Gospel according to Matthew may be described as a manual of instruction in the Christian way of life... The instruction is gathered around the story of Jesus, who by his words and deeds has inaugurated the kingdom of heaven - the reign of God on earth. "34 Itulah sebabnya Injil Matius sering kali dianggap sebagai "Manual of Discipline," yaitu buku pegangan untuk hidup berdisiplin bagi orang Kristen. Hal inilah yang mendorong gereja pada waktu menyusun Kanon Perjanjian Baru, menempatkan Injil Matius sebagai urutan yang pertama. Sebagaimana yang dikatakan oleh William Barclay bahwa Injil Matius adalah Injil Pengajaran karena Matius mengumpulkan pengajaran-pengajaran Yesus di dalam Injil ini. ${ }^{35}$ Hal ini dapat terjadi karena Matius adalah salah satu dari ke-12 murid Tuhan Yesus. Ia dipilih oleh Tuhan Yesus sebagai muridNya yang tinggal bersama dengan Tuhan dan murid-murid lain, yang dengan sendirinya diajar oleh Tuhan Yesus dari dekat. Ia juga mendengarkan khotbah Tuhan Yesus kepada orang banyak serta menyaksikan begitu banyak mujizat yang dilakukan Tuhan Yesus.

Dengan demikian tulisannya relatif lebih mudah diterima oleh gereja daripada tulisan Markus, yang bukan salah satu dari ke-12 murid Tuhan. Sedang Markus lebih dikenal sebagai murid Petrus. Dengan demikian dapat diperkirakan bahwa gereja mula-mula menempatkan Injil Matius sebagai urutan pertama dan Injil Markus sebagai yang kedua, sehingga sampai sekarang urutan ini tetap dipertahankan, yaitu Matius, Markus, Lukas, dan Yohanes. Sebagai akibat dari kenyataan ini, maka

\footnotetext{
${ }^{27}$ Pasaribu, Eksposisi Injil Sinoptik, 14.

28 Ibid.

${ }^{29}$ Santoso, Theologi Matius: Intisari Dan Aplikasinya, 3.

${ }^{30}$ Morris, Teologi Perjanjian Baru, 157.

${ }^{31}$ Santoso, Theologi Matius: Intisari Dan Aplikasinya, 1.

${ }^{32}$ Ibid.

${ }^{33}$ Ibid.

${ }^{34}$ Ibid., 14.

${ }^{35}$ Ibid.
} 
Injil Matius adalah Injil yang paling banyak dibaca dan paling berpengaruh terhadap gereja serta kehidupan orang Kristen.

\section{Prinsip Hermenetika Injil}

Berdasarkan 4 jenis tipe sastra (genre) kanon Perjanjian Baru, setiap tipe sastra tersebut memiliki persoalan-persoalan eksegesis khusus serta ketentuan-ketentuan tersendiri meskipun pembaca masa kini menyadari bahwa tipe sastra tersebut juga memiliki hal-hal yang umum. Tipe sastra Injil berisi unit-unit mandiri dari cerita atau pengajaran yang telah ditetapkan di dalam konteknya oleh pada penginjil. ${ }^{36}$ Injil-injil juga merupakan pelajaran dan khotbah pastoral dalam bentuk tulisan yang menuntut suatu respons yang positif dan praktis dari setiap pembaca di segala zaman. ${ }^{37}$

Injil Matius ditulis dalam bahasa Yunani. Apabila diperiksa dari kesusasteraan Yunani, dapat dikatakan bahwa bahasa Yunani dalam Injil ini cukup baik, hampir setara dengan bahasa Yunani Lukas. ${ }^{38}$ Matius sangat memperhatikan gaya bahasa yang digunakannya lain halnya dengan Markus yang pada umumnya menggunakan bahasa yang sederhana. ${ }^{39}$ Namun demikian, Matius tetap memakai pola Ibrani, yaitu parelelismus yang berarti kita menemukan dua kalimat yang sejajar. ${ }^{40} \mathrm{Hal}$ itu seringkali muncul dalam ucapan-ucapan Tuhan Yesus dalam Injil Matius (misalnya Mat. 7:7-14).

Gordon D. Fee berupaya merumuskan langkah-langkah eksegesis kanon Perjanjian Baru berdasarkan jenis sastranya. Secara khusus dia memberikan beberapa langkah-langkah khusus tiap-tiap tipe sastra. ${ }^{41}$ Untuk kitab-kitab Injil, dia menawarkan 3 langkah unik yaitu: (1) tentukan sifat formal perikop atau kata-kata; (2) analisa perikop dalam sinopsis Injil; (3) analisa perikop dalam konteks ceritanya. ${ }^{42}$ Ketiga hal tersebut adalah langkah khusus yang harus digunakan oleh setiap penafsir Injil dalam Perjanjian Baru selain langkah-langkah umum sebelum dan sesudahnya.

\section{METODE}

Kajian ini menggunakan metode penelitian kualitatif dengan pendekatan literatur. Metode yang penulis gunakan adalah analisis deskriptif teks Matius 11:28 karena metode penelitian deskriptif (descriptive research) pada umumnya bersifat memaparkan atau menjelaskan hasil penelitian secara presisi. ${ }^{43}$ Penelitian ini dikatakan kualitatif deskriptif karena menekankan pada pendeskripsian teks Matius 11:28 dengan studi kepustakaan. ${ }^{44}$ Sedangkan prosedur penulisan dimulai dengan kajian literatur dari buku-buku yang terkait, jurnal-jurnal ilmiah, dan media lainnya yang berkorelasi dengan fokus penelitian. Dengan metode kualitatif deskriptif, pembaca dapat memahami makna "letih lesu dan berbeban berat" dalam teks Matius 11:28 berdasarkan prinsip Hermenetika yang penulis paparkan dalam penelitian ini dan memperbaiki kesalahan konsep dalam memaknai teks tersebut.

\footnotetext{
${ }^{36}$ Gordon D. Fee, New Testament Exegesis (Eksegesis Perjanjian Baru) (Malang: Literatur SAAT, 2011), 3.

${ }^{37}$ David K. Lowery, "Teologi Matius," in A Biblical Theology of New Testament (Malang: Gandum Mas, 2011), 18.

${ }^{38}$ De Heer, Injil Matius Pasal 1-22.

${ }^{39}$ Duyverman, Pembimbing Ke Dalam Perjanjian Baru.

${ }^{40}$ Ibid.

${ }^{41}$ Fee, New Testament Exegesis (Eksegesis Perjanjian Baru), 8-9.

${ }^{42}$ Ibid.

${ }^{43}$ Sonny Eli Zaluchu, "Strategi Penelitian Kualitatif Dan Kuantitatif Di Dalam Penelitian Agama," Evangelikal: Jurnal Teologi Injili dan Pembinaan Warga Jemaat 4, no. 1 (2020): 28.

${ }^{44}$ Sugiyono, Metode Penelitian Pendidikan: Pendekatan Kuantitatif, Kualitatif Dan $R$ \& D (Bandung: Alfabeta, 2014), 35-36.
} 


\section{HASIL DAN PEMBAHASAN \\ Perbandingan Terjemahan}

Sebagai perbandingan terjemahan untuk menganalisis variasi terjemahan teks Matius 11:28, penulis memilih beberapa terjemahan mayor dalam bahasa Indonesia, Inggris, dan Yunani. Perhatikan tabel perbandingan terjemahan di bawah ini:

Tabel 1. Perbandingan Terjemahan Teks Matius 11:28

\begin{tabular}{|c|c|}
\hline Versi & Terjemahan \\
\hline $\begin{array}{l}\text { Indonesia Terjemahan } \\
\text { Baru (ITB) }\end{array}$ & $\begin{array}{l}\text { Marilah kepada-Ku, semua yang letih lesu dan berbeban berat, Aku akan memberi } \\
\text { kelegaan kepadamu. }\end{array}$ \\
\hline $\begin{array}{l}\text { New International Version } \\
\text { (NIV) }\end{array}$ & Come to me, all you who are weary and burdened, and I will give you rest. \\
\hline King James Version (KJV) & Come unto me, all ye that labour and are heavy laden, and I will give you rest. \\
\hline Textus Receptus (TR) & 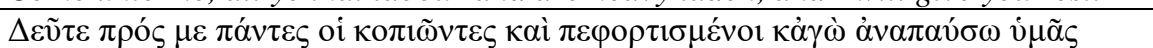 \\
\hline $\begin{array}{l}\text { Westcott and Hort New } \\
\text { Testament (WHO) }\end{array}$ & 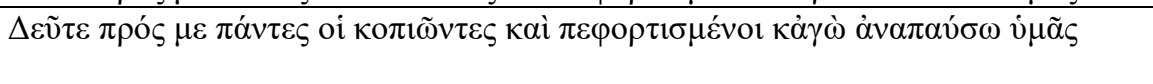 \\
\hline
\end{tabular}

Berdasarkan perbandingan terjemahan di atas, teks-teks mayor Yunani sama-sama

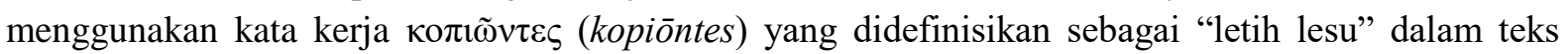
Bahasa Indonesia Terjemahan Baru (ITB). Hal yang menarik, dalam teks-teks Bahasa Inggris, yaitu King James Version dan New International Version terdapat perbedaan penggunaan kata tersebut. King James Version menggunakan kata "labour", sedangkan New International Version menggunakan kata "weary". Kata "labour" merupakan bentuk kata benda yang berarti "work, especially physical work" (bekerja, khususnya pekerjaan fisik). ${ }^{45}$ Kata "weary" berarti "very tired, especially after you have been working hard or doing something for a long time" (sangat lelah, khususnya setelah melakukan pekerjaan berat atau melakukan sesuatu dalam periode waktu yang sangat lama) ${ }^{46}$ Meskipun berbeda, arti dari kedua kata ini mirip yaitu keadaan "lelah karena melakukan sebuah pekerjaan."

Selanjutnya, untuk frase "berbeban berat" (dalam Indonesia Terjemahan Baru), Textus Receptus dan Westcott-Hort menggunakan kata kerja yang sama, yaitu $\pi \varepsilon \varphi о \rho \tau \imath \sigma \mu \varepsilon ́ v o r$ (pephortismenoi). King James Version dan New International Version pun menggunakan kata yang berbeda untuk merujuk hal tersebut, di mana King James Version menggunakan kata "heavy laden" sedangkan New International Version menggunakan kata "burdened". Kata "burdened" berarti "to give somebody a duty, responsibility, etc. that causes worry, difficulty or hard work" (memberikan seseorang sebuah pekerjaan, tanggung jawab dan lain-lain yang menyebabkan keletihan, kesusahan, atau kerja keras). ${ }^{47}$ Jadi, berdasarkan tabel perbandingan terjemahan di atas, frase "letih lesu dan berbeban berat" tidak menimbulkan kemungkinan terjemahan yang bervariasi. Terjemahan-terjemahan yang ada (Yunani dan Inggris), sudah memberikan pengertian yang sama dari penggunaan kata yang berbeda. Pengertian yang sama tersebut adalah frase "letih lesu dan berbeban berat" memiliki pengertian keadaan seseorang yang sangat lelah setelah melakukan sebuah pekerjaan atau tanggung

45 "Labour_1 Noun - Definition, Pictures, Pronunciation and Usage Notes | Oxford Advanced Learner's Dictionary at OxfordLearnersDictionaries.Com,” accessed January 18, 2021, https://www.oxfordlearnersdictionaries.com/definition/english/labour_1?q=labour.

46 "Weary_1 Adjective - Definition, Pictures, Pronunciation and Usage Notes | Oxford Advanced Learner's Dictionary at OxfordLearnersDictionaries.Com,” accessed January 18, 2021, https://www.oxfordlearnersdictionaries.com/definition/english/weary_1?q=weary.

47 “Burden_2 Verb - Definition, Pictures, Pronunciation and Usage Notes | Oxford Advanced Learner's Dictionary at OxfordLearnersDictionaries.Com,” accessed January 18, 2021, https://www.oxfordlearnersdictionaries.com/definition/english/burden_2?q=burdened. 
jawab yang berat dan dalam periode waktu yang sangat lama. Letih lesu dan berbeban berat adalah akibat, bukan penyebab.

\section{Pendekatan Kontekstual}

Konteks ayat ini merujuk kepada legalisme orang Yahudi dalam melakukan tuntutan hukum Taurat. Orang-orang Yahudi hidup dalam Taurat dan tradisi lisannya. Tafsiran dan aplikasi dari keduanya menghasilkan 613 peraturan (613 mitsvot) yang harus ditaati tanpa terkecuali. Legalisme Yahudi lebih mudah menghukum atau mengintimidasi daripada menolong seseorang yang mengalami kesulitan dalam hidup. Jelas ini sangat melelahkan jiwa manusia, tetapi di dalam Kristus manusia hidup dalam hukum yang memerdekakan (bdk: Gal. 5:1).

Dalam perikop yang berjudul "Ajakan Juruselamat” ini, Matius mengungkapkan ucapan syukur Yesus sebagai pendahuluan perikop, "Aku bersyukur kepada-Mu, Bapa, Tuhan langit dan bumi, karena semuanya itu Engkau sembunyikan bagi orang bijak dan orang pandai, tetapi Engkau nyatakan kepada orang kecil. Ya, Bapa, itulah yang berkenan kepada-Mu (Mat. 11:25).” William Barclay menyatakan bahwa pada pendahuluan ini Yesus mengungkapkan para rabi Yahudi, yaitu kaum intelektual menolak Yesus sementara orang-orang miskin, sakit, dan tidak dianggap menerima Dia. ${ }^{48}$ Dengan demikian, ayat 28 terikat secara konteks dengan ayat-ayat sebelum dan sesudahnya yaitu tentang penolakan rabi Yudaisme terhadap Yesus.

Mereka tidak hanya menolak Yesus, tetapi juga memberikan kuk kepada orang lain. Yesus pernah mengecam mereka dengan mengatakan, "Mereka mengikat beban-beban berat, lalu meletakkannya di atas bahu orang, tetapi mereka sendiri tidak mau menyentuhnya (Mat. 23:4)." Merekalah yang membuat banyak bangsa Israel mengalami letih lesu dan berbeban berat dengan meletakkan tuntutan-tuntutan hukum Taurat yang mereka sendiri tidak dapat lakukan dengan sempurna (Kis. 15:10). Pada ayat 26-27, Yesus pun mengklaim bahwa tidak ada seorang pun yang dapat mengenal Bapa selain Dia dan tidak ada seorang pun yang mengenal Dia selain Bapa. Klaim ini kembali menegaskan bahwa pengenalan seseorang akan Tuhan Yesus adalah sebuah anugerah yang besar, bukan hasil usaha manusia.

Berdasarkan pendekatan konteks Matius 11:25-30, pembaca seharusnya memahami bahwa perikop ini tidak berbicara tentang persoalan jasmaniah seperti permasalahan hidup sebagai manusia, tetapi persoalan hukum Taurat yang telah menjadi kuk bagi bangsa Yahudi. Sebagaimana metode penafsiran yang ditawarkan oleh Gordon D. Fee, seorang penafsir tidak boleh mengabaikan sinopsis cerita dalam satu perikop di dalam Injil-injil. ${ }^{49}$

\section{Pendekatan Gramatikal}

Dalam terjemahan-terjemahan Yunani, istilah "letih lesu" menggunakan kata "колı (kopiōntes) yang dapat juga diartikan "berusaha keras" atau "menjadi letih lesu" ${ }^{50}$ Pembaca dapat memahami bahwa letih lesu merupakan akibat, bukan sebab. Dapat disimpulkan bahwa letih lesu merupakan kondisi atau keadaan sebagai akibat dari sesuatu hal, bukan sebaliknya hal yang mengakibatkan sesuatu terjadi nantinya. Dari definisi ini, pembaca menerima kesan bahwa orang-orang yang dipanggil Tuhan adalah orang-orang yang berusaha keras melakukan sesuatu dalam hidupnya, bukan orang-orang yang letih lesu akibat permasalahan hidup. "This is an invitation particularly to those who are not yet his disciples. In the OT, the 'yoke' is often used as an image of being under one's

${ }^{48}$ William Barclay, Pemahaman Alkitab Setiap Hari: Injil Matius Pasal 11-28 (Jakarta: BPK Gunung Mulia, 2015), 21.

${ }^{49}$ Fee, New Testament Exegesis (Eksegesis Perjanjian Baru).

${ }^{50}$ B. F. Drewes, Wilfrid Haubeck, and Heinrich von Siebenthal, Kunci Bahasa Yunani Perjanjian Baru (Jakarta: BPK Gunung Mulia, 2010), 35. 
rule, particularly in relation to foreign rulers (e.g. Lev. 26:13; Isa. 9:4; 10:27)." "In (Ini adalah undangan khususnya bagi mereka yang belum menjadi murid-Nya. Dalam Perjanjian Lama, kata "kuk" sering digunakan sebagai gambaran berada di bawah pemerintahan seseorang, terutama dalam hubungannya dengan penguasa asing (misalnya Im. 26:13; Yes. 9:4; 10:27). Hal tersebut senada dengan apa yang disampaikan oleh France:

"Jesus issues his invitation to all who labour and are heavy laden. The last word is unusual, and reminds us of 23:4, where the scribes and Pharisees are accused of making the people carry 'heavy burdens' by their legalistic demands. Scribal religion was meant to honour God, but its effect was to condemn the ordinary Jew to hard labour." ${ }^{52}$ (Yesus memberikan undangannya kepada semua orang yang bekerja dan berbeban berat. Kata terakhir tidak biasa, dan mengingatkan kita pada Matius 23:4, di mana ahli Taurat dan orang Farisi dituduh membuat orang-orang memikul 'beban berat' dengan tuntutan legalistik mereka. Agama juru tulis dimaksudkan untuk menghormati Tuhan, tetapi efeknya adalah mengutuk orang Yahudi biasa untuk kerja paksa).

Yesus berbicara kepada orang-orang yang berusaha sekuat tenaga untuk mencari Allah dan menjadi orang yang baik. Pada akhirnya mereka menemukan fakta kemustahilan dalam pencarian tersebut dan berjalan menuju keputusasaan dan keletihan. ${ }^{53}$ Allah yang tidak terbatas tidak dapat dijumpai oleh manusia yang terbatas dan berdosa jika bukan Allah yang menyatakan diri-Nya terlebih dahulu. Hal ini kembali mengingatkan pembaca tentang tuntutan Zofar kepada Ayub, "Dapatkah engkau memahami hakekat Allah, menyelami batas-batas kekuasaan Yang Mahakuasa?” (Ayb. 11:7). Yesus memberikan ajakan mulia ini sebagai jawaban atas pencarian tanpa ujung dan obat atas keletihan orang-orang Yahudi. Dengan kata lain, Yesus adalah tempat perhentian terakhir atas pencarian tersebut. Yesus menawarkan anugerah kepada orang yang mau menerima anugerah tersebut. Yesus mengetahui tuntutan hukum Taurat menjadi beban bagi setiap orang yang diikat olehnya dengan larangan, "Jangan lakukan!" "Kuk hukum Taurat, sebagaimana para rabi menamakannya adalah sesuatu yang ternyata berat dan membebani, karena bersifat lahiriah dan bendawi (tidak pribadi). ${ }^{\circ 54}$ Tuntutan-tuntutan hukum Taurat sungguh suatu beban yang berat bagi orang yang memikulnya (Mat. 23:2-4).

Penafsiran populer di kalangan Kristen tentang ayat ini tidak dapat dibenarkan karena berada di luar konteks. Penulis telah memberikan satu contoh penafsiran populer pada bagian pendahulan artikel ini yang mengaitkan teks ini dengan persoalan jasmani. Salah satu hal yang harus dihindari oleh seorang penafsir adalah pengaruh denominasi atau pandangan teologinya. Seorang penafsir seharusnya tunduk pada teks dan setia pada konteks. Iman orang percaya sungguh meyakini bahwa Yesus sanggup melepaskan umat-Nya dari segala kesesakan dan pergumulan hidup secara jasmaniah. Meskipun demikian, Matius 11:28 tidak menekankan hal itu berdasarkan konteknya, melainkan merujuk pada orang yang mengeluh karena beratnya hukum Taurat yang penuh dengan ritual-ritual dan tradisi orangorang Farisi dan ahli Taurat yang terikat legalisme (bdk: Mat. 23:4, Luk. 11:46, Kis. 15:10). Mereka adalah orang-orang yang merasa bisa melunasi hutang dosanya dengan usaha sendiri, sehingga orang

\footnotetext{
${ }^{51}$ Samson L. Uytanlet and Kiem-Kiok Kwa, Matthew, ed. Federico G. Villanueva (Manila: Langham Global Library, 2017), 126.

${ }^{52}$ France, The Tyndale New Testament Commentaries: Matthew, 200.

${ }^{53}$ William Barclay, Pemahaman Alkitab Setiap Hari: Injil Matius Pasal 11-28 (Jakarta: BPK Gunung Mulia, 2015), 25.

${ }^{54}$ Tafsiran Alkitab Masa Kini 3: Matius-Wahyu (Jakarta: Yayasan Komunikasi Bina Kasih, 2006), 87.
} 
tersebut berusaha mati-matian untuk taat kepada Tuhan secara sempurna, tetapi selalu gagal. ${ }^{55}$ Kegagalan itu membuat dia berputus asa namun tidak menghilangkan beban yang justru semakin berat.

\section{Makna Teologis Matius 11:28}

Berdasarkan analisis teks Matius 11:28 di atas, maka makna teologis teks tersebut adalah sebagai berikut:

\section{Keselamatan adalah Anugerah Allah}

Keselamatan adalah anugerah yang diberikan oleh Allah kepada manusia. Tidak ada seorang pun yang dapat mengapai keselamatan melalui usahanya sendiri. Hal tersebut sangatlah mustahil, sebab tidak seorang pun yang benar (Rm. 3:10). Orang yang letih lesu dan berbeban berat dalam teks ini merujuk kepada orang atau sekelompok orang yang berusaha melakukan hukum Taurat dengan sempurna dengan tujuan mendapatkan keselamatan. Upaya mendapatkan keselamatan melalui perbuatan baik tersebut justru menghantarkan mereka ke dalam keadaan yang buruk, yaitu letih lesu dan berbeban berat. Tuntutan hukum Taurat menjadi beban yang mematikan bagi mereka. Bagi orangorang yang seperti inilah, undangan Yesus datang.

Konsep keselamatan oleh iman adalah teologi Kristen Alkitabiah. Allah adalah satu-satunya sumber keselamatan dan keselamatan adalah pemberian Allah semata. ${ }^{56}$ Berdasarkan konsep ini, maka keselamatan manusia sama sekali tidak ditentukan oleh perbuatan yang dilakukannya, melainkan berdasarkan anugerah dari Allah yang diterima melalui iman kepada Tuhan Yesus Kristus sebagai Tuhan dan Juruselamat (Ef. 2:8). Paulus menegaskan bahwa manusia yang berdosa diselamatkan secara cuma-cuma hanya oleh anugerah (Rm. 4:16). Meskipun demikian, manusia harus merespon anugerah Allah tersebut melalui iman kepada Tuhan Yesus Kristus. Jadi anugerah keselamatan menjadi efektif melalui iman kepada Tuhan Yesus Kristus. ${ }^{57}$

Dalam Matius 11:28, Yesus mengetahui beban yang dipikul oleh orang Israel, khususnya orang Farisi dan ahli Taurat dengan berusaha melakukan tuntutan hukum Taurat untuk memperoleh keselamatan. Hal itu adalah perbuatan yang sia-sia belaka. Yesus menyadari bahwa banyak dari antara orang Israel yang tidak mau menerima undangan untuk menikmati anugerah keselamatan, tetapi Ia datang untuk menyatakan anugerah itu melalui pengorbanannya di kayu salib.

\section{Yesus Kristus Menggenapi Hukum Taurat}

Yesus Kristus datang bukan untuk meniadakan hukum Taurat, tetapi menggenapinya (Mat. 5:17). Matius mencatat perkataan Yesus, bahwa tidak ada satu iota pun, atau satu pun bagian taurat akan berlalu. ${ }^{58}$ Yesus adalah Allah yang berinkarnasi menjadi manusia yang tidak berdosa. Hanya Dialah pribadi yang sanggup menggenapi semua tuntutan hukum Taurat. Segala sesuatu yang perlu dilakukan untuk membayar lunas hukuman atas dosa-dosa manusia dan mendapatkan keselamatan semua manusia sudah dikerjakan melalui kematian Yesus pada kayu salib. Karya penebusan Yesus Kristus di kayu salib adalah sempurna, satu kali untuk selama-lamanya (Ibr. 9:11-14).

Dalam Matius 11:28, Yesus memberikan undangan kepada mereka yang tidak sanggup melakukan tuntutan hukum Taurat secara sempurna. Memang tidak ada seorang manusia pun yang dapat menggenapi tuntutan hukum Taurat dengan sempurna selain Allah yang menjadi Manusia, yaitu

\footnotetext{
55 "Sanctification 2 : Not Alegalistic Piety (Matius 11:28-30)," accessed December 8, 2020, https://rec.or.id/article_49_Sanctification-2-:-Not-alegalistic-piety-(Matius-11:28-30).

56 Dessy Handayani, “Tinjauan Teologis Konsep Iman Dan Perbuatan Bagi Keselamatan," EPIGRAPHE: Jurnal Teologi dan Pelayanan Kristiani 1, no. 2 (2018): 91.

${ }^{57}$ George Eldon Ladd, Teologi Perjanjian Baru II (Bandung: Kalam Hidup, 1999), 201.

${ }^{58}$ David Pawson, Membuka Isi Alkitab Perjanjian Baru (Jakarta: Immanuel, 2017), 65.
} 
Tuhan Yesus Kristus. Oleh sebab itu, Dia layak menjadi Juru Selamat yang memberikan kelegaan kepada semua manusia yang mau datang untuk memenuhi undangan-Nya. Manusia diperhadapkan dengan banyaknya pilihan agama yang menawarkan jalan untuk mendapatkan keselamatan. ${ }^{59}$ Alkitab sebagai firman Allah menyatakan dengan tegas bahwa Yesus Kristus adalah satu-satunya jalan menuju kehidupan yang kekal bersama Bapa di Surga (Yoh. 14:6). Rasul-rasul dalam tuntunan Roh Kudus juga mendeklarasikan bahwa tidak ada nama lain yang olehnya manusia dapat diselamatkan, selain nama Tuhan Yesus Kristus (Kis. 4:12). Ini adalah fakta Alkitabiah yang tidak dapat digeser atau dihapuskan oleh kelompok manapun.

\section{KESIMPULAN}

Matius 11:28 telah dikumandangkan oleh sebagian pengkhotbah dan orang Kristen masa kini sebagai sebuah konsep yang tidak sesuai makna teks tersebut. Konsep populer yang muncul dari penafsiran tidak bertanggung jawab atas ayat tersebut adalah Yesus menawarkan kesembuhan, pemulihan ekonomi, pemulihan hubungan keluarga, dan persoalan hidup lainnya. Sesungguhnya, ajakan Juruselamat sebagaimana yang tertulis dalam Matius 11:28 memiliki makna teologis yang Kristosentris. Tuhan Yesus tetap konsisten terhadap tujuan dan motivasi-Nya berinkarnasi ke dunia untuk menyelamatkan yang hilang melalui pengorbanan-Nya di kayu salib. Tuhan Yesus menawarkan anugerah keselamatan yang hanya diperoleh melalui iman kepada orang-orang Yahudi yang kelelahan berjuang untuk melakukan tuntutan hukum Taurat. Dengan demikian, Ia pun mengundang semua manusia yang berusaha mendapatkan keselamatan jiwa dengan perbuatan untuk datang kepada Yesus dengan iman.

${ }^{59}$ Stephen Tong, Yesus Kristus Juruselamat Dunia (Surabaya: Momentum, 2005), vii. 


\section{DAFTAR PUSTAKA}

Barclay, William. Pemahaman Alkitab Setiap Hari: Injil Matius Pasal 11-28. Jakarta: BPK Gunung Mulia, 2015.

Blomberg, Craig L., and Jennifer Foutz Markley. A Handbook of New Testament Exegesis. Malang: Gandum Mas, 2018.

Drewes, B. F., Wilfrid Haubeck, and Heinrich von Siebenthal. Kunci Bahasa Yunani Perjanjian Baru. Jakarta: BPK Gunung Mulia, 2010.

Duyverman, M. E. Pembimbing Ke Dalam Perjanjian Baru. Jakarta: BPK Gunung Mulia, 2012.

Fee, Gordon D. New Testament Exegesis (Eksegesis Perjanjian Baru). 3rd ed. Malang: Literatur SAAT, 2011.

France, R. T. The Tyndale New Testament Commentaries: Matthew. Surabaya: Momentum, 2007.

Handayani, Dessy. "Tinjauan Teologis Konsep Iman Dan Perbuatan Bagi Keselamatan.” EPIGRAPHE: Jurnal Teologi dan Pelayanan Kristiani 1, no. 2 (2018): 91.

De Heer, J. J. Injil Matius Pasal 1-22. Jakarta: BPK Gunung Mulia, 2013.

Ladd, George Eldon. Teologi Perjanjian Baru II. Bandung: Kalam Hidup, 1999.

Lowery, David K. "Teologi Matius.” In A Biblical Theology of New Testament. Malang: Gandum Mas, 2011.

Morris, Leon. Teologi Perjanjian Baru. Malang: Gandum Mas, 2006.

Pasaribu, Marulak. Eksposisi Injil Sinoptik. Malang: Gandum Mas, 2005.

Pawson, David. Membuka Isi Alkitab Perjanjian Baru. Jakarta: Immanuel, 2017.

Pfeiffer, Charles F., and Everett F. Harrison. The Wycliffe Bible Commentary. Malang: Gandum Mas, 2011.

Santoso, David Imam. Theologi Matius: Intisari Dan Aplikasinya. Malang: Literatur SAAT, 2009.

Sibarani, Yosua. "Studi Evaluatif Model Khotbah Topikal Bagi Pengkhotbah Kristen.” Juteolog: Jurnal Teologi 1, no. 1 (2020): 59-76.

Sugiyono. Metode Penelitian Pendidikan: Pendekatan Kuantitatif, Kualitatif Dan $R \& D$. Bandung: Alfabeta, 2014.

Sutanto, Hasan. Hermenetika: Prinsip Dan Metode Penafsiran Alkitab. Malang: Literatur SAAT, 2007. Tenney, Merrill C. Survei Perjanjian Baru. Malang: Gandum Mas, 2011.

Tong, Stephen. Yesus Kristus Juruselamat Dunia. Surabaya: Momentum, 2005.

Uytanlet, Samson L., and Kiem-Kiok Kwa. Matthew. Edited by Federico G. Villanueva. Manila: Langham Global Library, 2017.

Zaluchu, Sonny Eli. "Strategi Penelitian Kualitatif Dan Kuantitatif Di Dalam Penelitian Agama." Evangelikal: Jurnal Teologi Injili dan Pembinaan Warga Jemaat 4, no. 1 (2020): 28.

Zuck, Roy B. Hermenetika: Basic Bible Interpretation. Malang: Gandum Mas, 2014.

"Burden_2 Verb - Definition, Pictures, Pronunciation and Usage Notes | Oxford Advanced Learner's Dictionary at OxfordLearnersDictionaries.Com." Accessed January 18, 2021. https://www.oxfordlearnersdictionaries.com/definition/english/burden_2?q=burdened.

"Labour 1 Noun - Definition, Pictures, Pronunciation and Usage Notes | Oxford Advanced Learner's Dictionary at OxfordLearnersDictionaries.Com." Accessed January 18, 2021. https://www.oxfordlearnersdictionaries.com/definition/english/labour_1?q=labour.

"Letakkanlah Beban Anda | Santapan Rohani." Accessed December 8, 2020. https://santapanrohani.org/2017/01/08/letakkanlah-beban-anda/.

"Matius." Ensiklopedi Alkitab Masa Kini Jilid II M-Z. Yayasan Komunikasi Bina Kasih, 2011.

"Sanctification 2: Not Alegalistic Piety (Matius 11:28-30)." Accessed December 8, 2020. https://rec.or.id/article_49_Sanctification-2-:-Not-alegalistic-piety-(Matius-11:28-30).

Tafsiran Alkitab Masa Kini 3: Matius-Wahyu. Jakarta: Yayasan Komunikasi Bina Kasih, 2006.

"Weary_1 Adjective - Definition, Pictures, Pronunciation and Usage Notes | Oxford Advanced Learner's Dictionary at OxfordLearnersDictionaries.Com." Accessed January 18, 2021. https://www.oxfordlearnersdictionaries.com/definition/english/weary_1?q=weary. 